\title{
Perbandingan Akurasi Berbagai Formula untuk Mengestimasi Laju Filtrasi Glomerulus pada Penderita Karsinoma Nasofaring Stadium Lanjut Sebelum Mendapat Kemoterapi Cisplatin
}

\author{
Camelia Khairun Nissa, ${ }^{1}$ Amaylia Oehadian, ${ }^{2}$ Abdul Hadi Martakusumah, ${ }^{3}$ Yussy Afriani Dewi $^{4}$ \\ ${ }^{1}$ Departemen Ilmu Penyakit Dalam, ${ }^{2}$ Divisi Hemato-onkologi Medik, Departemen Ilmu Penyakit Dalam, ${ }^{3}$ Divisi \\ Ginjal Hipertensi, Departemen Ilmu Penyakit Dalam, ${ }^{4}$ Departemen Telinga Hidung Tenggorokan-Kepala Leher \\ Fakultas Kedokteran Universitas Padjadjaran/Rumah Sakit Dr. Hasan Sadikin Bandung
}

\begin{abstract}
Abstrak
Cisplatin adalah obat sitotoksik dengan efektivitas tinggi dan digunakan secara luas, termasuk pada karsinoma nasofaring (KNF). Salah satu keterbatasan penggunaan cisplatin adalah nefrotoksisitas, terutama pada tubulus ginjal. Formula HARUS 15-30-60 dan HADI merupakan formula baru dalam menilai laju filtrasi glomerulus (LFG) dengan memperhitungkan fungsi tubulus. Penelitian ini bertujuan mengetahui perbandingan akurasi formula Cockroft-Gault (CG), Modification of Diet in Renal Disease (MDRD), HARUS 15-30-60, dan HADI dengan klirens kreatinin dalam menilai LFG pada penderita KNF stadium lanjut. Dilakukan penelitian analitik komparatif dengan rancangan potong lintang. Data diambil dari rekam medik penderita KNF yang akan mendapat kemoterapi cisplatin di Departemen Ilmu Penyakit Dalam Rumah Sakit Dr. Hasan Sadikin Bandung mulai Agustus 2012 sampai Agustus 2013. Data dianalisis menggunakan ANOVA dan uji concordance correlation coefficient (CCC). Subjek penelitian terdiri atas 70 subjek, 28 perempuan (40\%) dan 42 laki-laki (60\%), dengan usia rata-rata 42 $\pm 12,3$ tahun. Estimasi LFG berdasarkan MDRD, CG, dan HADI berbeda dengan klirens kreatinin $(p<0,05)$, sedangkan estimasi LFG berdasarkan HARUS 15-30-60 tidak berbeda ( $p>0,05)$. Formula HARUS 15-30-60 memiliki CCC 0,401 , lebih besar daripada CG (CCC=0,387), HADI $(C C C=0,258)$, dan MDRD $(0,136)$. Simpulan, formula HARUS 15-30-60 lebih akurat dibanding dengan formula CG, HADI, dan MDRD dalam menilai LFG pada penderita KNF stadium lanjut. [MKB. 2015;47(1):42-8]
\end{abstract}

Kata kunci: Cockroft-Gault, formula HADI dan HARUS 15-30-60, klirens kreatinin, laju filtrasi glomerulus, modification of diet in renal disease

\section{The Accuracy Comparison of Various Formulas for Estimating Glomerular Filtration Rate in Advanced Nasopharyngeal Carcinoma Patients Before Administration of Cisplatin}

\begin{abstract}
Cisplatin is a widely used and highly effective cytotoxic agent, including in nasopharyngeal carcinoma (NPC). One of the side effects of cisplatin is nephrotoxicity, especially in tubulus. HARUS 15-30-60 and HADI are new formulas for estimating glomerular filtration rate (GFR) which also calculate tubular function. The aim of this study was to compare the accuracy of Cockroft-Gault (CG), modification of diet in renal disease (MDRD), HARUS 15-30-60 and HADI formula with creatinine clearance in assessing GFR. This was cross sectional study with comparative design in patients with advanced NPC before administration of cisplatin in Dr. Hasan Sadikin General Hospital. Data were collected from August 2012 until August 2013 and analyzed using ANOVA and concordance correlation coefficient test (CCC). There were 70 patients, consisted of $28(40 \%)$ females and $42(60 \%)$ males. The mean age was $42 \pm 12.3$ years. MDRD, CG, and HADI were different with creatinine clearance $(p<0.05)$, whereas no difference was found between HARUS 15-30-60 and creatinine clearance ( $p>0.05$ ). HARUS 15-30-60 with creatinine clearance had CCC 0.401, greater than CG (CCC $=0.387$ ), HADI ( $C C C=0.258)$, and MDRD (CCC $=0.136)$. In conclusion, HARUS 15-30-60 formula is more accurate than CG, HADI, and MDRD formula in assessing renal function (GFR) in patients with advanced NPC. [MKB. 2015;47(1):42-8]
\end{abstract}

Key words: Cockroft-Gault, creatinine clearance, estimated glomerular filtration rate, HADI and HARUS 15-3060 formula, modification of diet in renal disease

Korespondensi: Camelia Khairun Nissa, dr, Sp PD, PBLUD RS Sekarwangi, Jl. Siliwangi Cibadak, Kabupaten Sukabumi, mobile 081315749641,e-mail: ckhnisa@yahoo.com 


\section{Pendahuluan}

Cisplatin (Cis-diamminedichloroplatinum(II), CDDP) adalah obat sitotoksik dengan efektivitas yang tinggi dan telah digunakan secara luas. Cisplatin banyak digunakan pada kanker organ solid, termasuk keganasan kepala leher. ${ }^{1,2}$ Salah satu keterbatasan penggunaan cisplatin adalah nefrotoksisitas. Presentasi serius nefrotoksisitas cisplatin adalah acute kidney injury (AKI) yang ditemukan sebanyak $20 \%$ sampai $30 \%{ }^{3}$ Literatur lain menyatakan angka sekitar $50-75 \% 0^{4,5}$

Karsinoma nasofaring atau KNF merupakan keganasan kepala dan leher yang paling sering di kawasan di Asia Tenggara. ${ }^{6}$ Insidens KNF pada laki-laki sekitar 2-3 kali lebih banyak bila dibandingkan dengan perempuan. ${ }^{7}$ Walaupun KNF sering kali didapatkan pada usia 50-59 tahun tetapi terjadi peningkatan insidensi pada usia orang dewasa dan usia yang lebih muda. ${ }^{8}$ Di Indonesia, KNF juga merupakan karsinoma terbesar dari jumlah kasus keganasan kepala dan leher, terbanyak terjadi pada usia di atas 40 tahun dengan prevalensi sebesar 4,7/100.000 penduduk per tahun. ${ }^{9}$ Di Departemen Telinga Hidung Tenggorokan-Kepala Leher (THT-KL) Rumah Sakit Dr. Hasan Sadikin Bandung dari data periode 2006-2010 didapatkan 493 kasus KNF dan merupakan keganasan tertinggi (47\%) dari seluruh keganasan kepala leher. ${ }^{10}$

Penilaian fungsi ginjal harus dilakukan secara rutinsebelum pemberian cisplatin. Evaluasi tersebut tidak cukup dengan pemeriksaan kreatinin serum tetapi memerlukan pemeriksaan fungsi ginjal lain yaitu klirens kreatinin atau laju filtrasi glomerulus (LFG). ${ }^{11,12}$ Klirens kreatinin sering dipergunakan untuk menentukan besarnya LFG. Divisi Hematoonkologi Medik Fakultas Kedokteran Universitas Padjadjaran dan Rumah Sakit Dr. Hasan Sadikin Bandung (FKUP/RSHS) masih mempergunakan klirens kreatinin sebagai suatu syarat pemeriksaan fungsi ginjal prekemoterapi pada penderita KNF yang akan mendapatkan kemoterapi cisplatin. Pemeriksaan klirens kreatinin dilakukan dengan mengumpulkan urin selama 24 jam. Kelemahan pemeriksaan klirens kreatinin adalah senantiasa ada bias dalam penampungan urin 24 jam. Baku emas (gold standard) untuk mengukur LFG ini adalah klirens inulin dan metode radiofarmaka tetapi keduanya tidak praktis untuk penggunaan sehari-harikarena menghitung klirensinulin tidak mudah pengerjaannya, sedangkan pemeriksaan radiofarmaka mudah dikerjakan namun mahal. Untuk mengatasi hal itu dilakukan perhitungan konversi kadar kreatinin serum menjadi LFG yang diestimasi dengan memakai formula, antara lain dengan menggunakan rumus Modification of Diet in Renal Disease (MDRD) atau formula Cockcroft-Gault (CG), sebagaimana tercantum dalam pedoman internasional dan rekomendasi dari K/DOQI (Kidney Disease Outcomes Quality Initiative) dan KDIGO (Kidney Disease: Improving Global Outcomes). ${ }^{4,13}$

Indonesia belum mempergunakan formula MDRD dan CG di tingkat pelayanan primer. Di samping banyak yang tidak mengingatnya, formula dengan rumus yang sulit dan membutuhkan komputer untuk perhitungannya seperti MDRD membuat dokter di pelayanan primer cenderung tidak memakainya. Salah satu hal yang mungkin menjadi penyebab kekurangakuratan formula MDRD dan CG adalah dikarenakan kedua formula tersebut hanya memakai kadar kreatinin serum (creatinine based) sebagai variabel utamanya. Variabel lain yang dimasukkan ke dalam formula tersebut adalah variabel yang dapat memengaruhi produksi kreatinin serum antara lain gender dan usia. Kreatinin mempunyai kelemahan yaitu pada keadaan gangguan faal ginjal terdapat sebagian kreatinin yang disekresi oleh tubulus, sedangkan pada keadaan normal kreatinin hanya difiltrasi glomerulus dan tidak disekresi atau direabsorbsi oleh tubulus.

Tubulus mempunyai peranan yang cukup penting dalam mengatur faal ginjal sebagaimana ditunjukkan dengan berbagai penelitian yang banyak dilakukan akhir-akhir ini. Saat ini telah dibentuk suatu formula yang mempunyai rumus sederhana tetapi lebih akurat karena formula ini menambahkan dua variabel yaitu kadar ureum serum dan albuminuria ke dalam permodelan pembentukan formula baru (HARUS 15-30-60 dan HADI) untuk mengukur LFG yang diestimasi. Dengan penambahan dua variabel yang mewakili fungsi tubulus tersebut, diharapkan formula baru ini dapat menghasilkan nilai LFG yang lebih mendekati nilai baku emas dibandingkan dengan estimasi LFG oleh formula MDRD maupun CG. ${ }^{13}$

Formula HARUS 15-30-60 dan HADI sudah divalidasi untuk dapat menilai LFG pada penderita gagal ginjal kronik. Formula HARUS 15-30-60 itu merupakan formula yang paling mendekati nilai LFG yang diperiksa dengan menggunakan metode radiofarmaka.$^{13}$ Belum terdapat penelitian tentang keakuratan formula HARUS 15-30-60 dan HADI dalam menilai LFG pada penderita dengan fungsi ginjal yang normal. Penelitian ini memiliki tujuan untuk mengetahui perbandingan akurasi formula Cockroft-Gault (CG), Modification of Diet in Renal Disease (MDRD), HARUS 15-30-60, dan HADI dengan klirens kreatinin dalam menilai LFG pada penderita KNF stadium lanjut. 


\section{Metode}

Penelitian ini menggunakan data sekunder dari rekam medik penderita KNF yang mendapat kemoterapi cisplatin yang dirawat di ruang Fresia 2 Departemen Ilmu Penyakit Dalam Rumah Sakit Dr. Hasan Sadikin Bandung mulai Agustus 2012 sampai Agustus 2013 dan memenuhi kriteria inklusi serta tidak termasuk kriteria eksklusi. Kriteria inklusi: penderita KNF stadium III, IVa, dan IVb, usia $\geq 18$ tahun, penderita KNF yang akan mendapatkan terapi kemoradiasi konkuren cisplatin, memiliki data lengkap variabel yang akan dianalisis, sediaan biopsi itu berasal dari biopsi nasofaring, status performa $0-2$, kadar hemoglobin $>10 \mathrm{~g} / \mathrm{dL}$, dan kadar trombosit normal. Kriteria eksklusi yaitu kreatinin klirens $<60 \mathrm{~mL} /$ menit, penderita dengan kemoradiasi konkuren cisplatin yang tidak lengkap, terdapat keganasan lain selain KNF, gangguan hemostasis (secara klinis), SGOT/SGPT $\geq 3 \times$ normal, penyakit hati kronik, gagal jantung dekompensata (klinis), diabetes melitus, wanita hamil (klinis), infark miokardium, penyakit serebrovaskular (klinis), infeksi akut (klinis), vaskulitis dengan penyakit kolagen (klinis), dan gambaran histopatologis yaitu well differentiated carcinoma. Pengambilan data itu dilakukan menurut urutan kedatangan. Penelitian ini adalah suatu penelitian analitik komparatif numerik berpasangan. Bila dengan Uji Kolmogorov-Smirnov memiliki data yang berdistribusi normal maka dipergunakan uji statistik ANOVA yang dilanjutkan dengan analisis
Post Hoc-Bonferroni dan uji kesamaan dengan concordance correlation coefficient (CCC). Bila distribusi tidak normal, dilakukan uji statistik dengan Uji Friedman. Kemaknaan ditentukan berdasarkan $\mathrm{p}<0,05$ dengan piranti lunak SPSS 17.0.

\section{Hasil}

Subjek penelitian terdiri atas 70 orang yang memenuhi kriteria inklusi dan tidak termasuk eksklusi. Karakteristik subjek penelitian dapat dilihat pada Tabel 1. Subjek terdiri atas penderita KNF laki-laki 42 orang (60\%) dan perempuan 28 orang $(40 \%)$. Perbandingan nilai LFG dengan klirens kreatinin dan estimasi LFG (CG, MDRD, HADI, dan HARUS 15-30-60) sebelum mendapat kemoterapi cisplatin dengan uji ANOVA dapat dilihat pada Tabel 2. Uji statistik dengan ANOVA mendapatkan nilai $p<0,05$, hal ini berarti bahwa ada satu atau beberapa kelompok yang berbeda rata-ratanya secara signifikan. Uji analisis post hoc dengan Bonferroni (Tabel 3) mendapatkan MDRD, CG, dan HADI berbeda bermakna dengan klirens kreatinin $(p<0,05)$, sedangkan formula HARUS 15-30-60 tidak berbeda bermakna dengan klirens kreatinin $(p>0,05)$. Hal ini berarti bahwa formula HARUS 15-30-60 yang paling mendekati nilai klirens kreatinin. Perbandingan nilai rata-rata (mean) klirens kreatinin dengan estimasi LFG memakai formula CG, MDRD, HARUS 15-30-60, dan HADI dapat dilihat pada

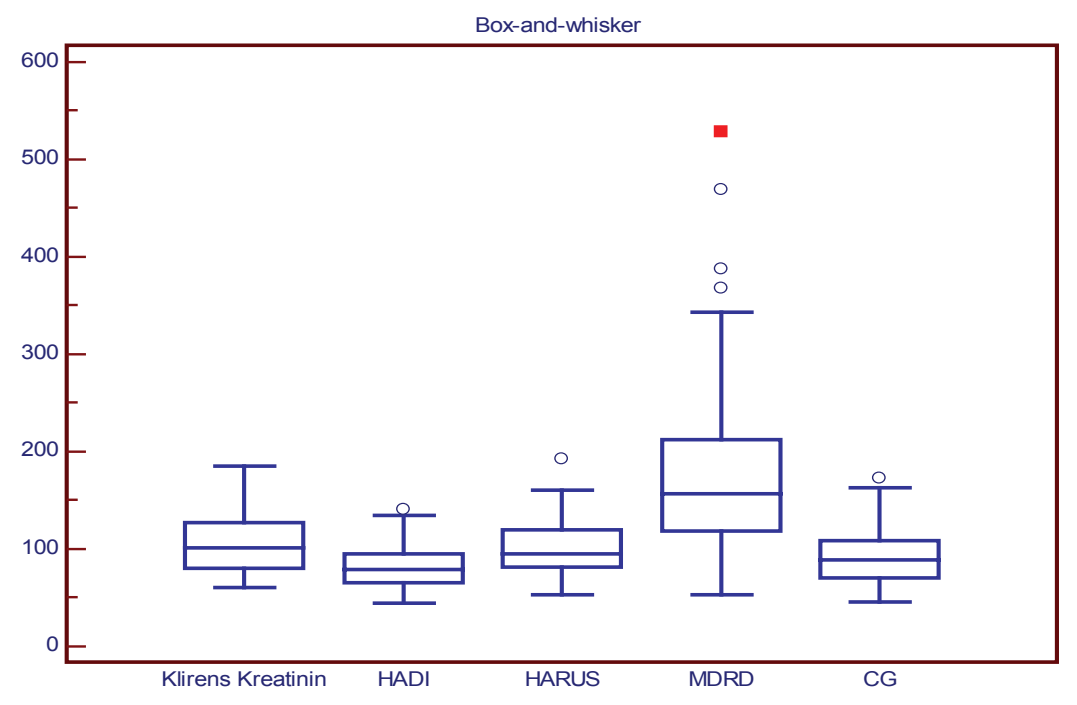

Gambar 1 Grafik Box Plot Perbandingan Nilai Rata-Rata \pm SB Klirens Kreatinin dan Estimasi LFG dengan Formula CG, MDRD, HARUS 15-30-60, dan Hadi 
Tabel 1 Karakteristik Subjek Penelitian pada penderita KNF Stadium Lanjut Sebelum Mendapat Kemoterapi Cisplatin

\begin{tabular}{|c|c|c|c|}
\hline \multirow{2}{*}{ Karakteristik } & \multirow{2}{*}{$\begin{array}{l}\text { Total } \\
\mathbf{n}=70\end{array}$} & \multicolumn{2}{|c|}{ Uji Normalitas } \\
\hline & & $\mathbf{p}$ & Distribusi \\
\hline \multicolumn{4}{|l|}{ Usia (tahun) } \\
\hline Mean \pm SB & $42 \pm 12,3$ & 0,200 & Normal \\
\hline$<20$ & $1(2 \%)$ & & \\
\hline $20-39$ & $28(40 \%)$ & & \\
\hline $40-59$ & $36(51 \%)$ & & \\
\hline$\geq 60$ & $5(7 \%)$ & & \\
\hline \multicolumn{4}{|l|}{ Jenis kelamin } \\
\hline Laki-laki & $42(60 \%)$ & & \\
\hline Perempuan & $28(40 \%)$ & & \\
\hline \multicolumn{4}{|l|}{ Berat badan (kg) } \\
\hline Median ( rentang) & $47,4(33-80)$ & 0,012 & Tidak normal \\
\hline \multicolumn{4}{|l|}{ Tinggi badan (cm) } \\
\hline Rata-rata \pm SB & $155,5 \pm 5,4$ & 0,060 & Normal \\
\hline \multicolumn{4}{|l|}{ Klirens kreatinin (mL/menit) } \\
\hline Rata-rata \pm SB & $104,08 \pm 27,5$ & 0,890 & Normal \\
\hline \multicolumn{4}{|c|}{ Estimasi LFG (mL/menit) dengan formula: } \\
\hline \multicolumn{4}{|l|}{ CG } \\
\hline Rata-rata \pm SB & $91,53 \pm 28,8$ & 0,583 & Normal \\
\hline \multicolumn{4}{|l|}{ MDRD } \\
\hline Rata-rata \pm SB & $181,96 \pm 96,93$ & 0,101 & Normal \\
\hline \multicolumn{4}{|l|}{ HARUS $15-30-60$} \\
\hline Rata-rata \pm SB & $100,59 \pm 28,53$ & 0,412 & Normal \\
\hline \multicolumn{4}{|l|}{ HADI } \\
\hline Rata-rata \pm SB & $81,03 \pm 21,98$ & 0,557 & Normal \\
\hline
\end{tabular}

Keterangan: SB: simpangan baku

Gambar 1. Gambar tersebut menunjukkan bahwa formula HARUS 15-30-60 yang paling mendekati nilainya klirens kreatinin. Hasil uji kesamaan pengukuran dengan mempergunakan CCC dapat dilihat pada Tabel 4 dan Gambar 2. Hasil analisis menggunakan CCC mendapatkan nilai estimasi LFG formula HARUS 15-30-60 dengan klirens kreatinin mempunyai koefisien sebesar 0,401 lebih besar dibanding dengan CG (CCC $=0,387)$, HADI $(C C C=0,258)$, dan MDRD $(0,136)$. Nilai CCC yang semakin mendekati 1 menunjukkan bahwa kedua variabel tersebut memiliki pengukuran yang semakin dianggap mendekati. Hasil analisis CCC dapat dilihat pada Gambar 2. Grafik tersebut memperlihatkan bahwa formula HARUS 15-30-
60 yang paling mendekati garis concordance dibanding dengan formula lain.

\section{Pembahasan}

Penelitian ini mendapatkan nilai LFG rata-rata dengan klirens kreatinin yaitu $104,08 \pm 27,5 \mathrm{~mL} /$ menit, formula CG sebesar $91,53 \pm 28,8 \mathrm{ml} /$ menit, formula MDRD 181,96 $\pm 96,93 \mathrm{~mL} / \mathrm{menit}$, formula HADI 81,03 $\pm 21,98 \mathrm{~mL} /$ menit, dan formula HARUS 15-30-60 sebesar 100,59 $\pm 28,53 \mathrm{~mL} /$ menit. Hal ini sesuai dengan rekomendasi dari K/DOQI, NKF, dan NKDEP yang dilaporkan oleh Myers dkk. ${ }^{11}$ dan Dash dkk. ${ }^{12}$ yang mensyaratkan 

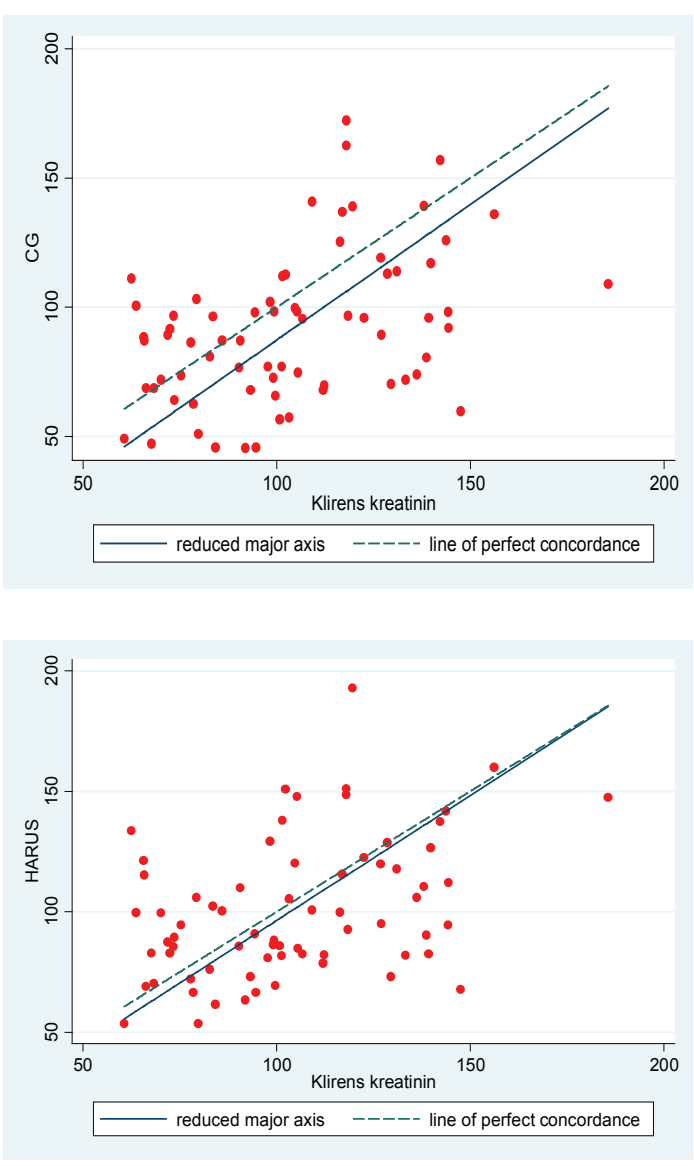

Gambar 2 Grafik Scatter Plot Concordance

batas nilai LFG sebelum kemoterapi cisplatin $\geq 60$ $\mathrm{mL} / \mathrm{mnt}$ untuk mencegah nefrotoksisitas.

Hasil uji statistik ANOVA didapat nilai $p<0,05$, hal ini berarti bahwa ada satu atau beberapa kelompok yang berbeda. Uji analisis post hoc dengan Bonferroni didapat bahwa MDRD, CG, dan HADI berbeda bermakna dengan klirens kreatinin $(\mathrm{p}<0,05)$, sedangkan HARUS 15-3060 tidaklah berbeda bermakna dengan klirens
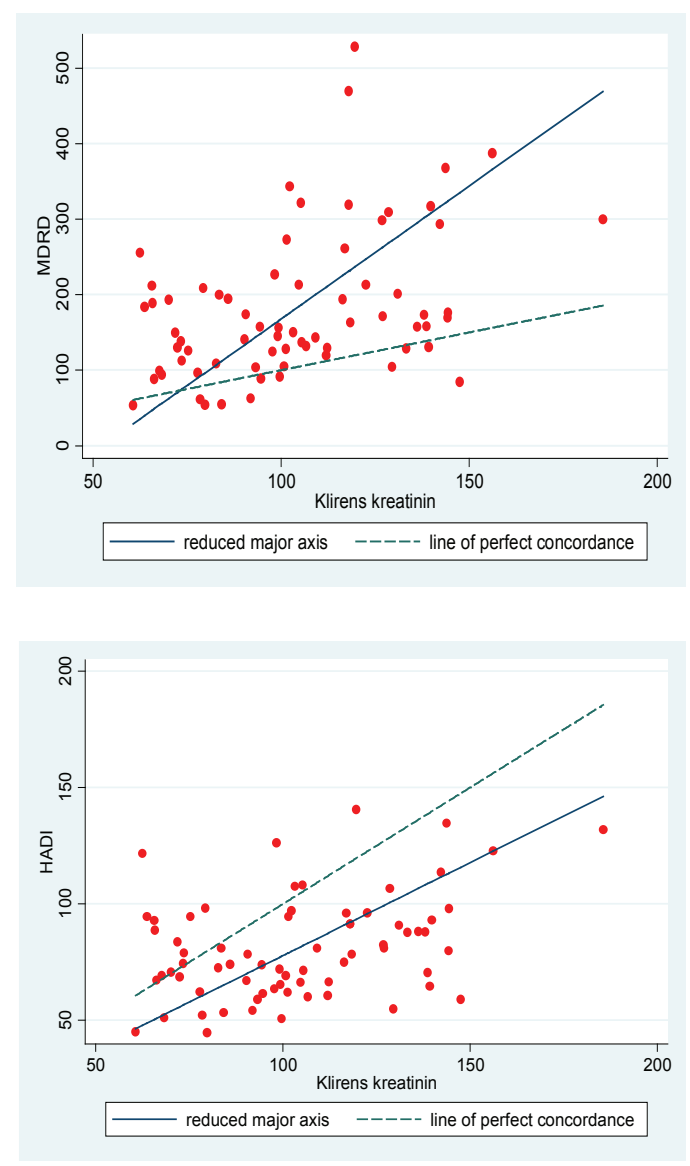

Tabel 2 Uji ANOVA Klirens Kreatinin dan Estimasi LFG dengan 4 Formula

\begin{tabular}{lcc}
\hline & Rata-rata \pm SB & p \\
\hline Klirens kreatinin & $104,083,29$ & $<0,001$ \\
HADI & $81,03 \pm 2,63$ & \\
HARUS 15-30-60 & $100,59 \pm 3,41$ & \\
MDRD & $181,96 \pm 11,59$ & \\
CG & $91,55 \pm 3,45$ & \\
\hline
\end{tabular}

Keterangan: SB: simpangan baku

kreatinin $(p>0,05)$. Hal ini berarti bahwa formula HARUS 15-30-60 yang paling akurat, sedangkan formula HADI masih di bawah formula HARUS 15-30-60 dan CG. Hasil analisis menggunakan CCC didapatkan hasil nilai estimasi LFG dengan formula HARUS 15-30-60 tadi dengan klirens kreatinin mempunyai koefisien sebesar 0,401 lebih besar dibanding dengan CG $(\mathrm{CCC}=0,387)$, HADI $(C C C=0,258)$, dan MDRD $(0,136)$. Nilai CCC

Keterangan: SB: simpangan baku 
Tabel 3 Hasil Analisis Post-hoc Bonferroni

\begin{tabular}{lcc}
\hline Klirens Kreatinin & Perbedaan rata-rata (IK 95\%) & p \\
\hline HADI & $23,046(13,36-32,73)$ & $<0,0001$ \\
HARUS 15-30-60 & $3,49(-7,11-14,09)$ & 1,0000 \\
MDRD & $-77,88(-108,76-47)$ & $<0,0001$ \\
CG & $12,53(2,07-22,99)$ & 0,0089 \\
\hline
\end{tabular}

Keterangan: IK: interval kepercayaan

yang semakin mendekati 1 , menunjukkan kedua variabel tersebut mempunyai pengukuran yang dianggap makin mendekati. Hal ini sesuai dengan penelitian yang dilakukan Martakusumah ${ }^{13}$ yang mendapatkan bahwa formula HARUS 15-30-60 mempunyai nilai rata-rata selisih LFG dengan baku emas yang paling kecil sebesar 0,02 mL/ menit, artinya nilai LFG HARUS $15-30-60$ paling mendekati baku emas dan selisih secara statistik tidak bermakna $(p>0,05)$, diikuti HADI dan CG yang memiliki rata-rata selisih LFG dengan baku emas yang tidak bermakna $(p>0,05)$. MDRD memiliki rata-rata selisih paling besar yaitu $-3,23 \mathrm{~mL} /$ menit $(\mathrm{p}<0,005)$.

Martakusumah $^{13}$ menyatakan berdasar atas penelitiannya bahwa formula HARUS 15-30-60 adalah formula yang paling akurat, diikuti oleh formula HADI. Formula MDRD adalah formula yang paling tidak akurat dibandingkan dengan formula yang lainnya. Formula HARUS 15-3060 dan HADI adalah formula yang menghasilkan estimasi LFG yang lebih akurat dibandingkan dengan estimasi yang dilakukan oleh MDRD, CG maupun CKD EPI $(\mathrm{p}<0,05)$.

Pada penelitian ini, akurasi formula HADI berada di bawah formula HARUS 15-30-60 dan CG, hal ini kemungkinan disebabkan formula HADI tidak memasukkan variabel usia dalam permodelannya oleh karena usia mempunyai hubungan dengan pengurangan jumlah nefron yang berfungsi baik. Selain itu, pada penelitian Martakusumah ${ }^{13}$ keempat formula dibandingkan dengan baku emas menggunakan radiofarmaka, sedangkan pada penelitian ini mempergunakan reference standard klirens kreatinin, formula CG menghitung klirens creatinin dan bukan LFG.

Berdasarkan karakteristik data dasar subjek penelitian ini, dapat dilihat bahwa usia rata-rata subjek penelitian $42 \pm 12,3$ tahun. Kelompok usia terbanyak terdapat antara 40 sampai 59 tahun yaitu sebanyak 36 (51\%) orang. Hasil penelitian tersebut menyatakan bahwa insidensi KNF di atas 50 tahun adalah sebesar 55-67\%. Hasil yang hampir sama juga dilaporkan oleh Kurnianda dkk. $^{9}$ Karakteristik penderita menurut jenis kelamin memperlihatkan bahwa sebagian besar subjek adalah laki-laki yaitu sebanyak 42 (60\%) orang, sedangkan perempuan sebanyak 28 $(40 \%)$ orang. Hal ini sesuai dengan penelitian yang telah dilaporkan oleh Kurnianda dkk. ${ }^{9}$ yang menyatakan perbandingan antara laki-laki dan perempuan penderita KNF adalah 2:1. Menurut Price dkk. ${ }^{7}$ perbandingan antara laki-laki dan perempuan masing-masing sebesar 57\%:17\%. Berat badan didapatkan rata-rata 47,4 kg dengan rentang 33-80 kg dan TB didapatkan 155,5 $\pm 5,4$ $\mathrm{cm}$.

Keterbatasan penelitian ini adalah estimasi LFG dengan formula CG, MDRD, HARUS 15-30-60, dan HADI dibandingkan dengan klirens kreatinin sebagai reference standard dan bukan dengan gold standard. Penelitian ini juga merupakan penelitian menggunakan data sekunder, sehingga diperlukan penelitian lanjutan untuk menguji

Tabel 4 Analisis Menguji Kesamaan Suatu Pengukuran Menggunakan CCC

\begin{tabular}{lccccc}
\hline & $\mathbf{n}$ & $\begin{array}{c}\text { Concordance } \\
\text { Correlation } \\
\text { Coefficient }\end{array}$ & IK 95\% & $\begin{array}{c}\text { Pearson } \boldsymbol{\rho} \\
\text { (Precision) }\end{array}$ & $\begin{array}{c}\text { Bias correction } \\
\text { Factor Cb } \\
\text { (Accuracy) }\end{array}$ \\
\hline CG - Klirens kreatinin & 70 & 0.387 & $0,189-0,555$ & 0,427 & 0,908 \\
MDRD - Klirens kreatinin & 70 & 0.136 & $0,058-0,212$ & 0,416 & 0,327 \\
HARUS - Klirens kreatinin & 70 & 0.401 & $0,187-0,579$ & 0,405 & 0,991 \\
HADI - Klirens kreatinin & 70 & 0.258 & $0,099-0,404$ & 0,380 & 0,680 \\
\hline
\end{tabular}

Keterangan: IK: interval kepercayaan 
formula HADI dan HARUS 15-30-60 dengan uji diagnostik menggunakan gold standard, dengan melibatkan sampel yang lebih besar dan di berbagai kota maupun provinsi sehingga dapat menjadi formula baru yang dapat digunakan sebagai penilai fungsi ginjal (LFG).

\section{Daftar Pustaka}

1. Miller RP, Tadagavadi RK, Ramesh G, Reeves WB. Mechanisms of cisplatin nephrotoxicity. Toxins. 2010;2:2490-518.

2. Moon HH, Seo KW, Yoon KY, Shin YM, Choi $\mathrm{KH}$, Lee SH. Prediction of nephrotoxicity induced by cisplatin combination chemotherapy in gastric cancer patients. World J Gastroenterol. 2011;17(30):3510-7.

3. Yao X, Panichpisal K, Kutzman N, Nugent K. Cisplatin nephrotoxicity: a review. Am J Med Sci. 2007;334:115-24.

4. Vacher VL, Rey JB, Bganis CI, Deray G, Daouphars M. Prevention of cisplatin nephrotoxicity: state of the art and recommendations from the European Society of Clinical Pharmacy special interest group on cancer care. Cancer Chemother Pharmacol. 2008;61:903-9.

5. Zhang Q Matsumara Y, Teratani T, Yoshimoto S, Mineno T, Nakagawa K, dkk. Evaluation of the observed cisplatin nephrotoxicity in adult cancer inpatients: a historical cohort study by using clinical data warehouse. J Health Sci. 2006;52(2):192-7.

6. Jayekumar A, Brickman TM. Review of nasopharyngeal carcinoma. ENT J. 2006; 85(3):168-73.
7. Price PM, Safirstein RL, Megyesi J. Protection of renal cells from cisplatin toxicity by cell cycle inhibitors. Am J Physiol Renal Physiol. 2004;286:F378-84.

8. Munir D. Karsinoma nasofaring. Medan: USU press; 2009.

9. Kurnianda J, Hardianti M, Harijadi, TaroenoHariadi K, Purwanto I, Haryuna S, dkk. Elevation of vascular endothelial growth factor in Indonesian advanced stage nasopharyngeal carcinoma. Kobe J Med Sci. 2009;55(2):E36-44.

10. Putri EB. Karakteristik penderita KNF di Departemen Ilmu Kesehatan THT-KL FKUP/ RSUP Dr. Hasan Sadikin Bandung periode tahun 2006-2010 [skripsi]. Bandung: Universitas Padjadjaran; 2011.

11. Myers GL, Miller WG, Coresh J, Fleming J, Greenberg N, Greene T, dkk. Recommendations for improving serum creatinine measurement: a report from the laboratory working of the national kidney disease education program. Clin Chemistry. 2006;52(1):5-18.

12. Dash A, Galsky MD, Vickers AJ, Serio AM, Koppie TM, Dalbagni G, dkk. Impact of renal impairment on eligibility for adjuvant cisplatin-based chemotherapy in patients with urothelial carcinoma of the bladder. American Cancer Society. 2006;107(3):50611.

13. Martakusumah AH. Formula baru untuk mengestimasi laju filtrasi glomerulus pada penderita penyakit ginjal kronik pradialisis [disertasi]. Jakarta: Universitas Indonesia; 2012. 